\title{
Intraosseous lipoma of the mandible: A diagnostic challenge
}

\author{
Lipoma intra-ósseo de mandíbula: um desafio diagnóstico
}

\begin{abstract}
Purpose: To report a rare case of intraosseous lipoma of the mandible and to discuss the most important features of the lesion, emphasizing the diagnostic piffall that this entity may represent for general dentists and radiologists.

Case description: An 18-year-old male patient presented an asymptomatic radiolucent lesion in the mandible in the region of the teeth 43 and 44 with no clinical alteration. After the incisional biopsy the histopathological exam revealed a capsulated lesion predominantly composed of mature adipose tissue and some areas of dystrophic calcification confirming the diagnosis of intraosseous lipoma. The lesion was surgically removed and no signs of recurrence could be observed after six months of follow-up.

Conclusion: Due to the unspecific clinical and radiographic features and its rarity the intraosseous lipoma of the mandible may be a diagnostic challenge for general dentists and radiologists. Therefore, the histopathological examination is required for the correct diagnosis of the lesion.
\end{abstract}

Key words: Bone Tumors; diagnosis; lipoma; mandible

\section{Resumo}

Objetivo: Relatar um caso raro de lipoma intra-ósseo em mandíbula e discutir os aspectos mais importantes desta lesão, enfatizando a desafio diagnóstico que esta entidade pode representar para cirurgiões dentistas e radiologistas.

Descrição do caso: Paciente do sexo masculino, 18 anos de idade apresentava uma lesão radiolúcida assintomática na mandíbula na região dos dentes 43 e 44 sem qualquer alteração clínica. Após a biópsia incisional, o exame histopatológico evidenciou uma lesão encapsulada composta majoritariamente por tecido adiposo benigno e algumas áreas de calcificações distróficas confirmando o diagnóstico de lipoma intra-ósseo. A lesão foi cirurgicamente removida e nenhum sinal de recorrência foi observado após seis meses de acompanhamento.

Conclusão: Devido às características clínicas e radiográficas inespecíficas e à sua raridade, o lipoma intra-ósseo de mandíbula pode representar um desafio diagnóstico para cirurgiões dentistas e radiologistas. Portanto, o exame histopatológico é fundamental para o correto diagnóstico da lesão.

Palavras-chave: Tumores ósseos; diagnóstico; lipoma; mandíbula

\section{Brunno Santos de Freitas Silva Fernanda Paula Yamamoto a Flávia Sirotheau Corrêa Pontes b Felipe Paiva Fonseca ${ }^{c}$ \\ Hélder Antônio Rebelo Pontes b Décio dos Santos Pinto Júnior ${ }^{\text {a }}$}

\footnotetext{
- Pos-graduate program in Oral Pathology, University of São Paulo, São Paulo, SP, Brazil

b Oral Pathology, Dental School, Federal University of Pará, Belém, PA, Brazil

c Pos-graduate program in Oral Pathology, State University of Campinas, Piracicaba, SP, Brazil
}

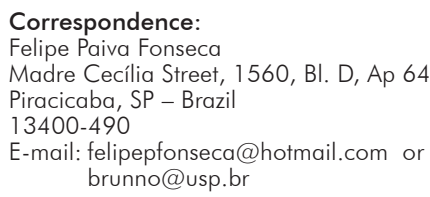

Conflict of Interest Statement: The authors state that there are no financial and personal conflicts of interest that could have inappropriately influenced their work.

Copyright: (C) 2011 Silva et al.; licensee EDIPUCRS This is an Open Access article distributed under the terms of the Creative Commons AttributionNoncommercial-No Derivative Works 3.0 Unported License. 


\section{Introduction}

Lipomas are common benign soft tissue neoplasms composed of mature adipose tissue with no evidence of cellular atipia $(1,2)$. Their overall incidence in the oral cavity ranges between $1 \%$ and $4.4 \%$ of all benign tumors, occurring in major salivary glands, buccal mucosa, lip, tongue, palate, vestibule, and floor of the mouth (3).

Despite the large amount of bone marrow in the human skeleton, intraosseous lipoma is considered infrequent $(1,2,4)$, accounting for less than $0.1 \%$ of all primary tumors of the bones (5). They occur more often in the metaphysis of long bones and calcaneous, with just 16 reported cases in mandible (2).

According to Cakarer et al. (2) the etiology and characteristics of the jaw lesions are not clear, stating the importance of documentation of each new case of intraosseous mandibular lipoma. Based on these findings, we present a rare case of mandibular lipoma.

\section{Case report}

An 18-year-old male patient was referred to our department by his dentist for evaluation of a painless radiolucency located on the right mandibular body, next to the apices of the canine and the first pre-molar teeth observed in a periapical radiograph. The extraoral physical examination revealed no alterations and the intraoral evaluation revealed no signs of cortical expansion or mucosal abnormality. The patient had no recalled prior trauma and his past medical history was non-contributory.
Cone Bean CT scans in a panoramic view revealed a solitary well circumscribed lesion, round in shape, with approximately $20 \mathrm{~mm}$ in diameter and sclerotic borders (Fig. 1). Cross-sectional view illustrated a regular bordered lesion with a slight expansion of the buccal osseous plate (Fig. 2).

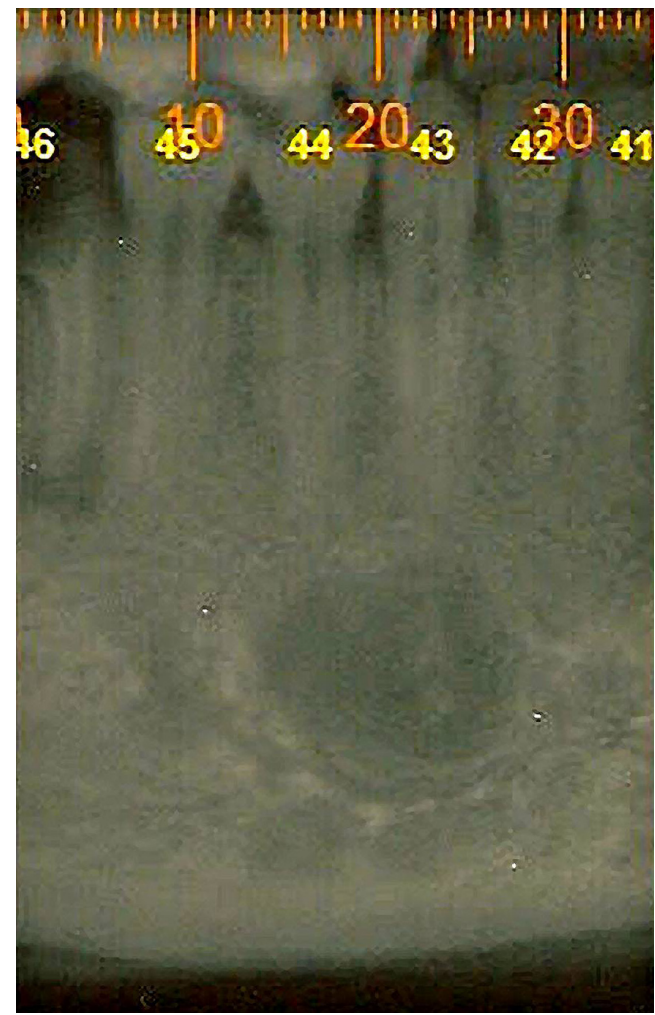

Fig. 1. Solitary lytic lesion with sclerotic borders in the right mandibular body.
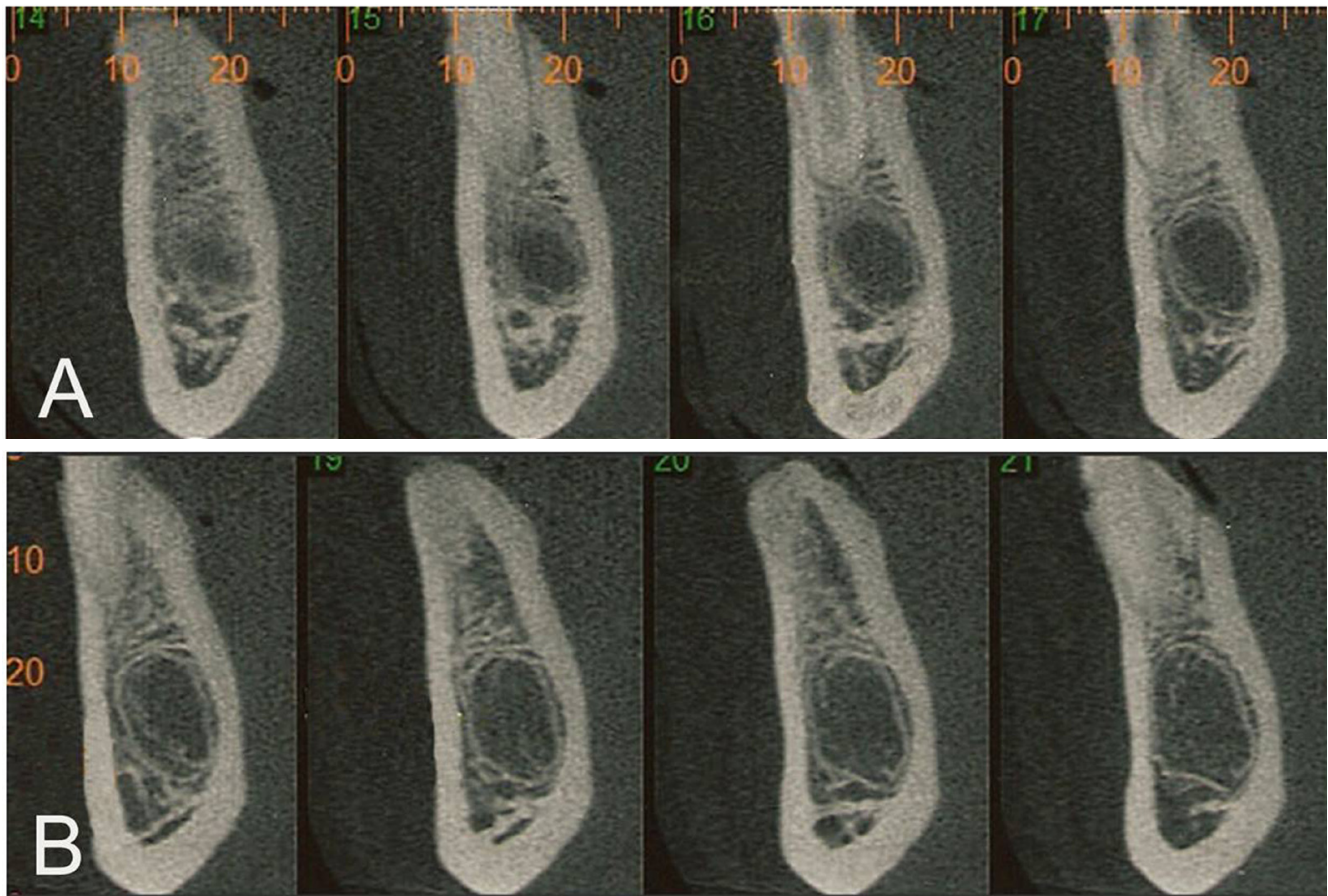

Fig. 2. Cone Bean CT scan in a cross-sectional view illustrating a regular bordered lesion with a slight expansion to the buccal osseous plate. 
Based on the CT findings and the clinical appearance the mainly differential diagnosis was traumatic bone cyst, keratocystic odontogenic tumor and ameloblastoma.

The aspiration of the lesion was done to evaluate the presence of cystic fluid, revealing a negative result. An incisional biopsy of the lesion was performed under local anesthesia. The histological examination of the excised specimen, using hematoxylin and eosin, revealed a lesion predominantly composed of mature adipose tissue (Fig. 3A), a few areas

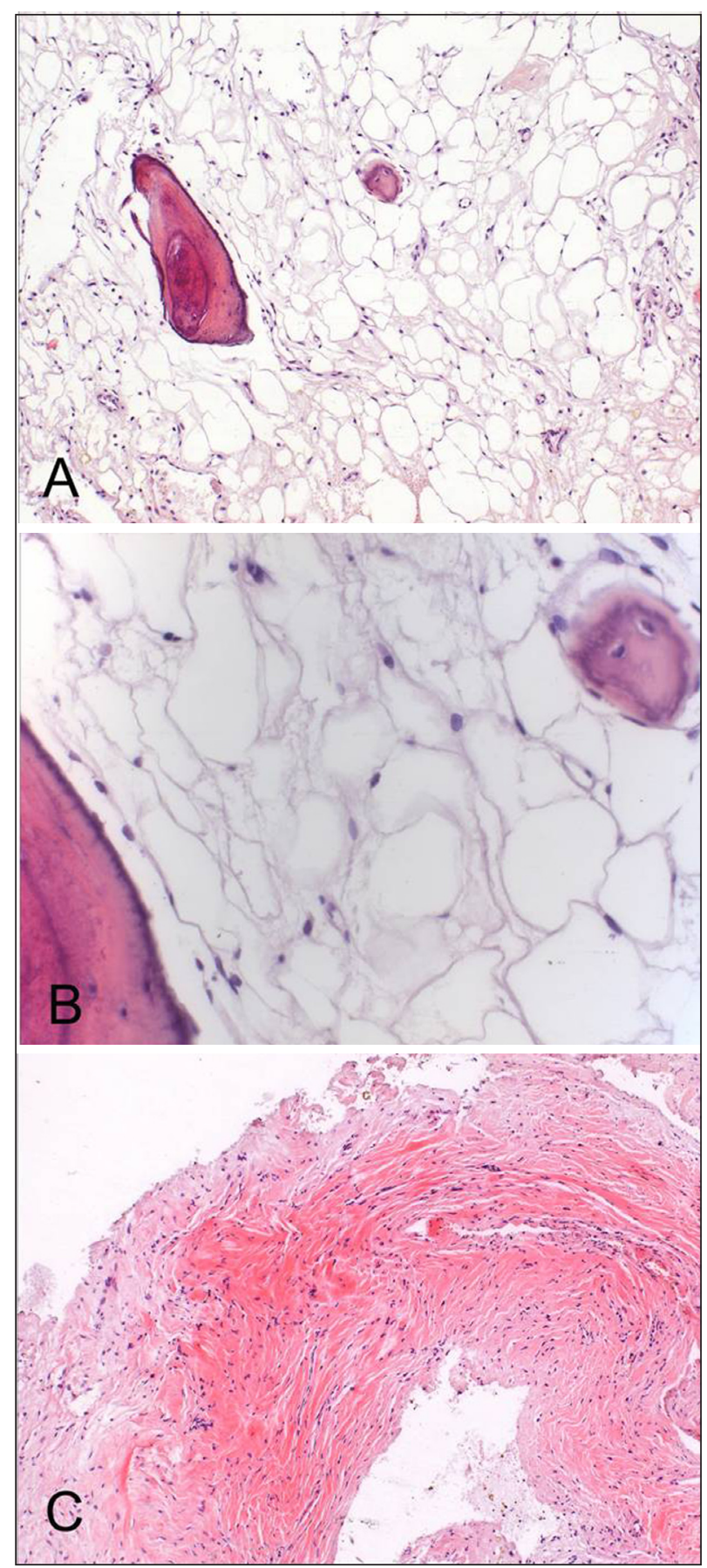

Fig. 3. (A) Photomicrography showing mature adipose tissue (H\&E; x100). (B) Areas of dystrophic calcification (H\&E; x200); (C) Presence of a connective tissue capsule (H\&E; x100). of dystrophic calcification (Fig. 3B), and a connective tissue capsule adjacent to the lesion (Fig. 3C), all features consistent with the diagnosis of intraosseous lipoma.

A second surgical procedure was undertaken aiming to remove the lesion completely. A buccal mucoperiosteal flap was performed under local anesthesia, exposing the cortical plate. The lesion, which was demarcated from the bone, was excised conservatively and no sign of recurrence was observed after six months of follow-up.

\section{Discussion}

Fat is present in the marrow of all bones, so it is not unexpected that the sites of involvement of lipomas include all regions of skeleton. However, intraosseous lipomas are unusual and are considered the rarest benign primary tumors of the bones (4). In the jaw, only 16 cases have been reported to date (Table 1). Because of the small number of cases, the etiology and characteristics of the jaw lesions are not fully established, emphasizing the importance of documentation of each new case of intraosseous lipoma (2).

The reported cases of intraosseous lipoma of the jaws revealed a slight preponderance of females (1.4:1), with the age raging from 20 to 65 years $(1,2,4,6-8)$. According to Buric et al. (1) there is a preference of intraosseous lipoma of the mandible to occur in fifth and sixth decades of life. A significant number of cases is asymptomatic $(1,2,4,6-8)$, being incidentally found on routine radiographs $(2,4,7,8)$, similar to the current report. However, swelling, pain and hypoesthesia are frequent symptoms of intraosseous lipoma $(1,9)$ depending mainly on location and size of tumor $(1,2,7)$. Radiologically, intraosseous lipoma appears as a well-defined lytic lesion $(1,2,4,9)$, frequently with large sclerotic borders $(1,2,4,7)$, and eventually presenting some mixed radiolucent/radiopaque areas (6).

The main differential diagnoses include keratocystic odontogenic tumor, simple bone cyst, bone marrow defect and early benign fibro-osseous lesions. Based on clinical and radiographic presentation, of a painless well circumscribed radiolucency, in the present case the main hypothesis was simple bone cyst. However, keratocystic odontogenic tumor and ameloblastoma could not be excluded, since the radiographic features of simple bone cyst are not diagnostic and may be confused with a variety of odontogenic and nonodontogenic radiolucent jaw lesions $(1,2,4,7)$. The rarity of intraosseous lipoma of the mandible may cause differential diagnostic problems, therefore, surgical exploration is necessary to establish the diagnosis (2).

Some theories concerning the etiology of intraosseous lipoma have been performed. Trauma, infarction and inflammation are the factors claimed to be causes for intraosseous lipoma in long bones (1). In the present case, trauma and inflammation do not seem to participate on the development of the lesion, once the patient reported no history of prior trauma or previous dental extraction and it appears to have no related sources of inflammation in the area of the lesion. Infarction could be a factor on 
the pathogenesis of intraosseous lipoma in the anterior mandible (1), which is supplied primarily by the inferior dental artery, and any obliteration of the nutrient vessels from this artery may cause some areas of infarction (2). According to Cakarer et al. (2) within these areas, fatty cells of bone marrow may accumulate to form a "lipomatous mass". However, the minimal hematopoiesis in anterior mandible does not support this theory. In addition, despite the close histological similarity to normal adipose tissue, most lipomas have chromosomal aberrations; therefore, it is plausible that genetic changes are involved in the development of the disease (10).

In conclusion, the diagnosis of intraosseous lipoma of the mandible may be a challenge, due to its rarity and clinical similarity with many other radiolucent jaw lesions; therefore, the histopathological examination is always required.

Table 1. Clinical, radiographic and histopathologic features of the previous reported intraosseous lipomas of the mandible.

\begin{tabular}{|c|c|c|c|c|c|c|c|c|}
\hline Authors & Age & Sex & Site & Clinical Features & $\begin{array}{l}\text { Trauma } \\
\text { History }\end{array}$ & $\begin{array}{l}\text { Differential } \\
\text { Diagnosis }\end{array}$ & $\begin{array}{c}\text { Radiographic } \\
\text { Features }\end{array}$ & $\begin{array}{l}\text { Histological } \\
\text { Diagnosis }\end{array}$ \\
\hline $\begin{array}{l}\text { Oringer } \\
(1948)\end{array}$ & 37 & $\mathrm{~F}$ & $\begin{array}{l}\text { Roots of lower second } \\
\text { molar }\end{array}$ & $\begin{array}{l}\text { Pain and pressure } \\
\text { during chewing }\end{array}$ & NS & NS & $\begin{array}{l}\text { Well-defined } \\
\text { radiolucency }\end{array}$ & Lipoma \\
\hline $\begin{array}{l}\text { Newman } \\
(1957)\end{array}$ & 65 & $M$ & $\begin{array}{l}\text { Associated to } \\
\text { impacted third molar }\end{array}$ & Asymptomatic & Yes & NS & $\begin{array}{l}\text { Well-defined } \\
\text { radiolucency }\end{array}$ & Fibrolipoma \\
\hline $\begin{array}{l}\text { Johnson } \\
\text { (1969) }\end{array}$ & 21 & $M$ & $\begin{array}{l}\text { Associated to } \\
\text { impacted second and } \\
\text { third molars }\end{array}$ & Pain and swelling & NS & Dentigerous Cyst & $\begin{array}{l}\text { Well-defined } \\
\text { radiolucency }\end{array}$ & Lipoma \\
\hline $\begin{array}{l}\text { Polte et al. } \\
\text { (1976) }\end{array}$ & 39 & $M$ & $\begin{array}{l}\text { From the second } \\
\text { premolar to the } \\
\text { second molar }\end{array}$ & $\begin{array}{l}\text { Hypoesthesia of the } \\
\text { lower lip and chin }\end{array}$ & No & $\begin{array}{l}\text { Osteoporotic bone } \\
\text { marrow defect }\end{array}$ & $\begin{array}{l}\text { Moderate } \\
\text { well-defined } \\
\text { radiolucency }\end{array}$ & Angiolipoma \\
\hline $\begin{array}{l}\text { Lewis et al. } \\
\text { (1980) }\end{array}$ & 56 & $\mathrm{~F}$ & Mandibular body & $\begin{array}{l}\text { Anesthesia of the } \\
\text { lip and chin }\end{array}$ & Yes & $\begin{array}{l}\text { Ameloblastoma; } \\
\text { Odontogenic cyst }\end{array}$ & $\begin{array}{l}\text { Multilocular } \\
\text { well-defined } \\
\text { radiolucency }\end{array}$ & Angiolipoma \\
\hline $\begin{array}{l}\text { Steiner et al. } \\
\text { (1981) }\end{array}$ & 50 & $M$ & $\begin{array}{l}\text { Associated to the roots } \\
\text { of the right third molar }\end{array}$ & Asymptomatic & No & Odontogenic cyst & $\begin{array}{l}\text { Well-defined } \\
\text { radiolucency }\end{array}$ & $\begin{array}{l}\text { Parosteal } \\
\text { lipoma }\end{array}$ \\
\hline $\begin{array}{l}\text { Miller et al } \\
\text { (1982) }\end{array}$ & 51 & $M$ & $\begin{array}{l}\text { Adjacent to a } \\
\text { horizontally impacted } \\
\text { left third molar }\end{array}$ & Asymptomatic & No & Dentigerous cyst & $\begin{array}{l}\text { Well-defined } \\
\text { radiolucency }\end{array}$ & Lipoma \\
\hline $\begin{array}{l}\text { Heir and } \\
\text { Geron (1983) }\end{array}$ & 43 & $\mathrm{~F}$ & $\begin{array}{l}\text { Left anterior border } \\
\text { of the mandibular } \\
\text { ramus }\end{array}$ & $\begin{array}{l}\text { Pain in the left side } \\
\text { of the face, neck } \\
\text { and temporal } \\
\text { region }\end{array}$ & NS & $\begin{array}{l}\text { TBC; hemorrhagic } \\
\text { bone cyst; residual } \\
\text { cyst; arteriovenous } \\
\text { malformation }\end{array}$ & $\begin{array}{l}\text { Well-defined } \\
\text { radiolucency }\end{array}$ & Lipoma \\
\hline $\begin{array}{l}\text { Barker and } \\
\text { Sloan (1986) }\end{array}$ & 53 & $\mathrm{~F}$ & $\begin{array}{l}\text { Associated to the root } \\
\text { of a impacted right } \\
\text { third molar }\end{array}$ & Asymptomatic & Yes & Inflammatory cyst & $\begin{array}{l}\text { Well-defined } \\
\text { radiolucency }\end{array}$ & Lipoma \\
\hline $\begin{array}{l}\text { Manganaro } \\
\text { et al. (1994) }\end{array}$ & 51 & $\mathrm{~F}$ & $\begin{array}{l}\text { Posterior left mandible } \\
\text { and mandibular ramus }\end{array}$ & Asymptomatic & Yes & NS & $\begin{array}{l}\text { Well-defined } \\
\text { radiolucid/ } \\
\text { radiopaque }\end{array}$ & Angiolipoma \\
\hline $\begin{array}{l}\text { Koami et al. } \\
\text { (1995) }\end{array}$ & 59 & $M$ & $\begin{array}{l}\text { Symphyseal } \\
\text { mandibular region }\end{array}$ & $\begin{array}{l}\text { Asymptomatic } \\
\text { swelling }\end{array}$ & NS & NS & $\begin{array}{l}\text { Well-defined } \\
\text { radiolucency }\end{array}$ & Lipoma \\
\hline $\begin{array}{l}\text { Buric et al. } \\
(2001)\end{array}$ & 62 & $\mathrm{~F}$ & $\begin{array}{l}\text { Sympheseal region } \\
\text { under retained roots }\end{array}$ & $\begin{array}{l}\text { Asymptomatic } \\
\text { swelling }\end{array}$ & Yes & $\begin{array}{l}\text { Cystic lesion; } \\
\text { odontogenic tumor; } \\
\text { fibrous dysplasia; } \\
\text { OBMD }\end{array}$ & $\begin{array}{l}\text { Multilocular } \\
\text { well-defined } \\
\text { radiolucency }\end{array}$ & Lipoma \\
\hline $\begin{array}{l}\text { Keogh et al. } \\
(2004)\end{array}$ & 56 & $\mathrm{~F}$ & $\begin{array}{l}\text { Associated to the } \\
\text { impacted right third } \\
\text { molar }\end{array}$ & Asymptomatic & No & NS & $\begin{array}{l}\text { Well-defined } \\
\text { radiolucency }\end{array}$ & Lipoma \\
\hline $\begin{array}{l}\text { Colella et al. } \\
(2005)\end{array}$ & 20 & $\mathrm{~F}$ & Posterior left mandible & Asymptomatic & No & $\begin{array}{l}\text { Radicular cyst; TBC; } \\
\text { CGCG; intraosseous } \\
\text { neurilemmoma; KOT; } \\
\text { aneurismal bone cyst; } \\
\text { odontogenic myxoma; } \\
\text { ameloblastoma }\end{array}$ & $\begin{array}{l}\text { Well-defined } \\
\text { radiolucency }\end{array}$ & Lipoma \\
\hline $\begin{array}{l}\text { Darling and } \\
\text { Daley (2005) }\end{array}$ & 22 & $\mathrm{~F}$ & $\begin{array}{l}\text { Anterior mandible-- } \\
\text { not associated with the } \\
\text { apex of the anterior } \\
\text { teeth }\end{array}$ & Asymptomatic & No & $\begin{array}{l}\text { CGCG; early benign } \\
\text { fibro-osseous lesion; } \\
\text { TBC; KOT; } \\
\text { ameloblastoma; } \\
\text { glandular odontogenic } \\
\text { cyst; odontogenic } \\
\text { myxoma; and OBMD }\end{array}$ & $\begin{array}{l}\text { Well-defined } \\
\text { radiolucency }\end{array}$ & Lipoma \\
\hline $\begin{array}{l}\text { Cakarer et al } \\
(2009)\end{array}$ & 45 & $\mathrm{~F}$ & $\begin{array}{l}\text { Anterior mandible - } \\
\text { associated to the apex } \\
\text { of the anterior teeth }\end{array}$ & Asymptomatic & No & $\begin{array}{l}\text { KOT; odontogenic } \\
\text { myxoma; early benign } \\
\text { fibro-osseous lesion; } \\
\text { CGCG }\end{array}$ & $\begin{array}{l}\text { Well-define } \\
\text { radiolucency }\end{array}$ & Lipoma \\
\hline $\begin{array}{l}\text { Present case } \\
(2010)\end{array}$ & 18 & $M$ & Right mandibular body & Asymptomatic & No & KOT; TBC & $\begin{array}{l}\text { Well-defined } \\
\text { radiolucency }\end{array}$ & Lipoma \\
\hline
\end{tabular}

NS: Not Specified; KOT: Keratocystic Odontogenic Tumor; CGCG: Central Giant Cell Granuloma; TBC: Traumatic Bone Cyst; OBMD: Osteoporotic Bone Marrow Defect. 
1. Buric N, Krasic D, Visnjic M, Katic V. Intraosseous mandibular lipoma: a case report and review of the literature. J Oral Maxillofac Surg 2001;59:1367-71.

2. Cakarer S, Selvi F, Isler SC, Soluk M, Olgac V, Keskin C. Intraosseous lipoma of the mandible: a case report and review of the literature. Int J Oral Maxillofac Surg 2009;38:900-2.

3. Furlong MA, Fanburg-Smith JC, Childers EL. Lipoma of the oral and maxillofacial region: Site and subclassification of 125 cases. Oral Surg Oral Med Oral Pathol Oral Radiol Endod 2004;98:441-50.

4. Darling MR, Daley TD. Radiolucent lesion of the anterior mandible. Oral Surg Oral Med Oral Pathol Oral Radiol Endod 2005;99:529-31.

5. Eyzaguirre E, Liqiang W, Karla GM, Rajendra K, Alberto A, Gatalica Z. Intraosseous lipoma. A clinical, radiologic, and pathologic study of 5 cases. Ann Diagn Pathol 2007; 11:320-5.

6. Manganaro AM, Hammond HL, Williams TP. Intraosseous angiolipoma of the mandible: a case report and review of the literature. J Oral Maxillofac Surg 1994;52:767-9.

7. Colella G, Strocchi R, Lanza A, Piattelli A. Intraosseous lipoma. J Endod 2003;29: 535-7.

8. Keogh PV, McDonnell D, Toner M. Intraosseous mandibular lipoma (IML): a case report and review of the literature. J Ir Dent Assoc 2004;50:132-4.

9. Koami T, Nishijima Y, Nishijima K. A case of intraosseous lipoma of the mandible. Jpn J Oral Maxillofac Surg 1995;24:875.

10. Castilho RM, Squarize CH, Nunes FD, Pinto Junior DS. Osteolipoma: a rare lesion in the oral cavity. Br J Oral Maxillofac Surg 2004;42:363-4. 